\title{
Optimal Timing for Delayed Umbilical Cord Clamping to Improve Hemoglobin Level after Birth
}

\author{
$1^{\text {st }}$ Dyah Puji Astuti \\ Program Studi Kebidanan Program \\ DIII, STIKES Muhammadiyah \\ Gombong \\ Gombong, Indonesia \\ dyahpuji090384@gmail.com
}

\author{
$2^{\text {nd }}$ Hastin Ika Indriyastuti \\ Program Studi Kebidanan Program \\ DIII, STIKES Muhammadiyah \\ Gombong \\ Gombong, Indonesia
}

\author{
$3^{\text {rd }}$ Eka Novyriana \\ Program Studi Kebidanan Program \\ DIII, STIKES Muhammadiyah \\ Gombong \\ Gombong, Indonesia
}

\begin{abstract}
Background: Delayed clamping of the umbilical cord is known to increase iron level in newborns. Optimal time for delayed clamping of umbilical cord is not known clearly. Objectives: To know the optimal time for delayed clamping of umbilical cord to improve hemoglobin level after birth. Methods: This study used experimental design which divided in three groups with different treatment; delayed umbilical cord clamping within during two minutes after birth; delayed umbilical cord clamping within three - seven minutes or / until its stop pulsed; and delayed umbilical cord clamping within till two hours. Results: the optimal time to improve hemoglobin level in after birth was delayed umbilical cord clamping within two hours, the average of the highest hemoglobin level after birth was $19.61 \mathrm{gr} \%$, while the mean of hemoglobin level of afterbirth in two minutes was lower, $2.65 \mathrm{~g} \%$ and in three till seven minutes was lower mean, 3,16gr\%. Conclusion: The optimal time to increase hemoglobin level in newborns is the delayed cord clamping for 2 hours treatment, with the average infant mortality rate of $19.61 \mathrm{gr} \%$.
\end{abstract}

Keywords-Delayed clamping of the umbilical cord, hemoglobin, after birth

\section{INTRODUCTION}

Anemia is a problem in developing countries such as Indonesia. The reproductive women and children often experiencing anemia. Iron is needed for the process of oxygenation into the brain and child growth. The process of the fetus to be baby is an important part of the process of child development that can be affected by the quality of human resources. During the pregnancy period, the oxygenation of the baby is got through the placenta, the mother' blood is transfused to the baby so that it can affect hemoglobin, hematocrit, blood volume, and the brain gets enough oxygen supply (Astrianti, Pangemanan, Bernolian, \& Yakub, 2012; Kosim, S, \& Sudarmanto, 2009; Rabe, Reynolds, \& Diaz-Rossello, 2007). The blood transfusion from mother to the infant may contribute between one-quarter and one-third of the total blood volume in newborns $(80-85 \mathrm{ml} / \mathrm{kg})$ and also delayed umbilical clamping cord might reduce the risk of hypovolemic complications, complications, and disability.
Delayed clamping of the umbilical cord is also known can decrease the prevalence of cerebral hemorrhage and sepsis in preterm (Mercer, 2016). Moreover, it can increase iron level in newborns. Astrianti et al., (2012) and WHO (2013) conducted the study about the time of delayed umbilical clamping cord with applied time between 1-3 minutes, and 3-7 minutes or until its stop pulsed. But, the optimal time for delayed umbilical clamping cord still unclear.

The objective of these study was: 1). Finding the effective method of delayed umbilical clamping cord still unclear to increase hemoglobin level after birth; 2). Identifying the effect of delayed umbilical clamping cord in newborn to hemoglobin level, placental release time and the first pain time. This study conducted at once to answer the optimal time in delayed umbilical clamping cord which still unclearly

\section{MATERIALS AND METHODS}

This study used experimental method approach, consist of three groups of different treatment. Group one conducted delayed umbilical cord clamping within during two minutes after birth; group two conducted delayed umbilical cord clamping within three - seven minutes or / until its stop pulsed; and group three did delay umbilical cord clamping within two hours and placental release. After conducted treatment group, then hemoglobin level and bilirubinemia were measured with lab tests. The study conducted in three different places: 1). Permata Ibu Clinic, conducted delayed umbilical cord clamping within during two minutes after birth; 2). Independent midwife practice (IMP) Hariyati, conducted delayed umbilical cord clamping within three - seven minutes or / until its stop pulsed; 3). Restu Bunda Hospital, conducted delay umbilical cord clamping within two hours and placental release.

Time of study started in June - September 2017. Collecting data process: 1). Asked permit and explanation in each study location; 2). Chose the pregnant women within criteria inclusion; 3). Observed umbilical cord clamping time; 4). Took blood sample babies 
(hemoglobin) to conducted lab tests; 5). Observed the health status of babies; 6). Data collection and analysis.

The population of this study was all case of childbirth in June - September 2017. Independent variable in this study was delayed umbilical cord clamping, and hemoglobin bilirubinemia in the new birth, placental release, the first pain time as the dependent variable. Each women pregnancy did observation about hemoglobin level in trimester III, gestational age (preterm, a term, post term), parity (primipara, multipara, Grande multipara), and factor of mother old $(<20,20-35,>35)$, in the: gender, and birth weight.

For data analysis using a t-test, ANOVA, and chisquare while for multivariate analysis using logistic regression test. The subject of this study is human, so that needed an ethical clearance for the feasibility of the research process.

\section{RESULTS}

A. The effect of delayed umbilical cord clamping to decrease hemoglobin level of new birth

TABLE I. THE EFFECT OF DELAYED UMBILICAL CORD CLAMPING TO DECREASE HEMOGLOBIN LEVEL OF NEW BIRTH

\begin{tabular}{|l|l|l|l|l|l|}
\hline & \multicolumn{5}{|c|}{ deviation } \\
\hline & mean & SD & P & average & $*$ CI 95\% \\
\hline Treatments & & & & & \\
\hline 2 minutes & 16.96 & 1.22 & 0.003 & -2.65 & $-4.37--0.92$ \\
\hline 3-7 minutes & 16.45 & 3.13 & 0.001 & -3.16 & $-4.87--1.43$ \\
\hline 2 hours (Ref) & 19.61 & 3.30 & & & \\
\hline
\end{tabular}

According to table I, that average of hemoglobin level in 2 minutes group was average $2,65 \mathrm{gr} \%$ lower than 2 hours group. The result above that delayed umbilical cord clamping during 2 minutes and 3-7 minutes influence hemoglobin level within $\mathrm{P}$ value $(0,003$ and 0,001$)$.

B. Delayed umbilical cord clamping to hemoglobin level in infant within 2-4 month.

TABLE II. DELAYED UMBILICAL CORD CLAMPING TO HEMOGLOBIN LEVEL IN INFANT WITHIN 2-4 MONTHS

\begin{tabular}{|l|r|r|r|c|c|}
\hline & & & & Deviation & \\
\hline & \multicolumn{1}{|c|}{ Mean } & sd & P & average & *CI 95\% \\
\hline Treatments & & & & & \\
\hline 2 minutes & 13.25 & 1.21 & 0.001 & 2.0 & $1.09-3.00$ \\
\hline 3-7 minutes & 11.36 & 1.39 & 0.737 & 0.16 & $-0.79-1.11$ \\
\hline 2 hours (Ref) & 11.20 & 1.82 & & & \\
\hline \multicolumn{6}{|c|}{ *CI: confident Interval } \\
\hline
\end{tabular}

According to table II, hemoglobin level of infants within 2-4 months showed that hemoglobin level of infants with two minutes treatment was average higher $2,0 \mathrm{gr} \%$ if compared two hours treatment group. Two hours treatment had the significant effect on hemoglobin level with 2-3 months, $\mathrm{P}$ value 0.001 .

C. Relationship between delayed umbilical cord clamping to placental release

TABLE III. RELATIONSHIP BETWEEN DELAYED UMBILICAL CORD CLAMPING TO PLACENTAL RELEASE

\begin{tabular}{|l|r|r|r|r|r|r|r|r|}
\hline & Placental Release Time & & & & \\
\hline & \multicolumn{3}{|c|}{ Fast } & Slow & $\chi^{2}$ & Pvalue & $* R R$ & $* * C I 95 \%$ \\
\hline & $\mathrm{n}$ & $\%$ & $\mathrm{n}$ & $\%$ & & & & \\
\hline Treatments & & & & & & & & \\
\hline 2 minutes & 7 & 35.0 & 13 & 65.0 & 1.25 & 0.337 & 0.70 & $0.33-1.46$ \\
\hline 3-7 minutes & 7 & 35.0 & 13 & 65.0 & 1.25 & 0.337 & 0.70 & $0.33-1.46$ \\
\hline 2 hours (Ref) & 10 & 50.0 & 10 & 50.0 & & & & \\
\hline
\end{tabular}

Based on table III showed that three treatments of

$(\mathrm{P}>0,05)$. delayed umbilical cord clamping above not having the relationship with the placental release, $\mathrm{P}$ value 0,337

D. The relationship between delayed umbilical cord clamping with the first pain time

TABLE IV. THE RELATIONSHIP BETWEEN DELAYED UMBILICAL CORD CLAMPING WITH THE FIRST PAIN TIME

\begin{tabular}{|c|c|c|c|c|c|c|c|c|}
\hline (2) & \multicolumn{4}{|c|}{ The first pain time } & \multirow[b]{2}{*}{$\chi^{2}$} & \multirow[b]{2}{*}{ Pvalue } & \multirow[b]{2}{*}{$R R$} & \multirow[b]{2}{*}{ CI 95\% } \\
\hline & \multicolumn{2}{|c|}{ pain } & \multicolumn{2}{|c|}{ No pain } & & & & \\
\hline & $n$ & $\%$ & $n$ & $\%$ & & & & \\
\hline \multicolumn{9}{|l|}{ treatments } \\
\hline 2 minutes & 3 & 15.0 & 17.0 & 85.0 & 0.00 & 1.000 & 1.00 & $0.22-4.37$ \\
\hline 3-7 minutes & 3 & 15.0 & 17.0 & 85.0 & 0.00 & 1.000 & 1.00 & $0.22-4.37$ \\
\hline 2 hours (Ref) & 3 & 15.0 & 17.0 & 85.0 & & & & \\
\hline
\end{tabular}

According to table IV, showed that delayed umbilical cord clamping not relation with the first pain 


\section{DISCUSSION}

The delayed umbilical cord clamping can increase consistently the hematological value and newborn iron status, on the other hand, it can promote neurological and cognitive development. When taking place an incidence of iron deficiency or anemia, this matter can be applied. It also can support the transition from intrauterine to extrauterine life, reducing hypovolemic damage and effects, and assisting the thermoregulation of newborns (Holvey, 2014). Based on the study result according to Holvey (2014) showed the longer of delayed umbilical cord clamping will increase the hemoglobin rate in newborns.

Several hypotheses suggest that early umbilical clamping cord has an effect on the newborn. Early clamping cord could reduce the blood volume required and causes hypovolemic damage because there is inhibiting capillary perfusion, it makes inflammation and an increased risk of infection in newborns. Besides reducing the blood volume, there is also a decrease in red blood cell mass, iron level and loss of hematopoietic stem cells, as well as developing some blood disorders and type 2 diabetes (Holvey, 2014). This is in line with the results of this study where delayed umbilical cord clamping with 2-minute treatment (the fastest delay time of cord clamping) increased mean bilirubin level compared with 3-7 treatment and 2 hours treatment, so it can be concluded that to get normal bilirubin normal birth it is necessary to delay longer cord clamping.

This study also showed that from the three treatments, only the treatment which conducted during 2 minutes was significantly associated with hemoglobin level of infants aged 2-4 months. This is possible because the status of hemoglobin level of infants aged 2-4 months influenced by many factors such as anemia during pregnancy, baby growth, low intake of iron from food (breast milk). Delayed umbilical cord clamping increases iron and decreases the incidence of anemia in infants (Kosim et al., 2009). The incidence of anemia in infants who require blood transfusion decreased 61\% after applying Delayed umbilical cord clamping (WHO, 2013). Delayed umbilical cord clamping increases the concentration of hemoglobin and iron which can decrease the risk of anemia in infants and iron deficiency at four to six months after birth (Andersson \& westas, 2011; Garofalo \& Abenhaim, 2012).

The three cord clamping treatments were unrelated to placental release, $\mathrm{P}$ value 0.337 ( $\mathrm{P}>0.05)$. This is because the placental release time of the umbilical cord in the newborn is influenced by several things, such as (a) the way of cord treatment, (b) the incidence of infection on the umbilical cord causes slowing and release of the umbilical cord, (c) this umbilical cord should not be sealed with anything as it may cause the cord to become moist thus slowing the cord drop and raising the risk of infection, (d) environmental sanitation conditions, due to unqualified measures or treatment including infant looms. So, it can be concluded that the delay time of umbilical cord clamping does not affect the time of cord release (WHO, 2013).
The third treatment of cord clamping does not correlate with the first pain time with $\mathrm{P}$ value 1,000 (P> 0.05 ). The results of this study are not related because the first pain time in newborns can be influenced by many factors such as nutritional intake (ASI), infant care, daily infant care, climatic conditions and environmental sanitation conditions (Wahab, 2000).

\section{v. CONCLUSIONS}

The optimal time to increase hemoglobin level in newborns is the delayed cord clamping for 2 hours treatment, with the average infant mortality rate of $19.61 \mathrm{gr} \%$. The mean of hemoglobin rate of newborn infants in the 2-minute treatment group had a mean of $2.65 \mathrm{gr} \%$ lower than hemoglobin level of the newborn in 2 hours group, and mean of hemoglobin rate of the newborn in 3-7 minutes group had mean 3,16gr\% lower than hemoglobin level of newborn treatment in 2 hours group. Treatment of 3-7 minutes showed a significant effect on bilirubin content with $\mathrm{P}$ value 0,013 and lower mean 1,22 than 2-hour treatment group. The highest bilirubin level was highest in the 2-minute treatment group with the mean (4.04). The three cord clamping delay treatments were unrelated to the time of clamping cord with $\mathrm{P}$ value 0.337 ( $\mathrm{P}>0.05$ ). The third treatment of cord clamping delay is not related to the first pain time with $\mathrm{P}$ value $1,000(\mathrm{P}>0.05)$.

\section{ACKNOWLEDGMENTS}

The author would like to thank LLDIKTI VI for funding this research and for all parties involved from midwives, midwives' assistants and clinics.

\section{REFERENCES}

[1] Andersson, O., \& westas, 1. h. (2011). effect of delayed versus early umbilical cord clamping on neonatal outcomes and iron status at 4 months : a randomized controlled trial. bmj, 343.

[2] Astrianti, L. R., Pangemanan, W. T., Bernolian, N., \& Yakub, K. (2012). Neonatal Haemoglobin and Haematocrit Level on Delayed Cord Clamping. Indonesia Obstetrics and Gynecology, 36(1).

[3] Dash, M. B., Murali, \& Rajareswari. (2014). Effect of Delayed Cord Clamping on Hemoglobin Level among Newborns in Rajiv Gandhi Goverment Women and Children Hospital, Puducherry. American Journal of Nursing Research, 2(1), 7-11.

[4] Garofalo, M., \& Haim A. Abenhaim, M., MPH. (2012). Early Versus Delayed Cord Clamping in Term and Preterm Births: A Review. Obstet Gynaecol Can(34(6)), 525-531.

[5] Holvey, N. (2014). the Imperative of Implementing Delayed Cord Clamping to Improve Maternal and Neonatal Outcomes. british journal of midwifery, 22(9).

[6] Kosim, M. S., S, Q., \& Sudarmanto, B. (2009). Pengaruh Waktu Penjepitan Tali Pusat Terhadap Kadar Hemoglobin dan Hematokrit Bayi Baru Lahir. Sari Pediatri, 10(5).

[7] Mercer, J. S. (2016). Delayed Cord Clamping in Very Preterm Infants Reduces the Incidence of Intraventricular Hemorrhage and Late-Onset Sepsis : A Randomized Controlled Trial. PEDIATRICS, 117 (4).

[8] Rabe, Reynolds, \& Diaz-Rossello. (2007). Early versus delayed umbilical cord clamping in preterm infants (Review). The Cochrane Library(4).

[9] Wahab, a. S. (2000). Ilmu Kesehatan Anak (Vol. 1). Jakarta: EGC.

[10] WHO. (2013). Delayed Clamping of The Umbilical Cord to Reduce Infant Anaemia: USAID. 